\title{
「複雑コミュニケーションサイエンス時限研究専門委員会 (CCS)」発足
}

\author{
複雑コミュニケーションサイエンス時限研究專門委員会 \\ 委員長 梅野 健 (独立行政法人情報通信研究機構) \\ 副委員長 岡本英二(名古屋工業大学) \\ 副委員長 田中久陽 (電気通信大学)
}

\section{1. 設立目的, 対象とする分野例}

本時限研究専門委員会は, 現在の情報通信の全ての階層, またこれを取り巻く情報通信環境, 人間や生体, 更にはSNSのよう なソーシャルコミュニケーションのメカニズムをも対象として, 現実的問題の本質・限界 ·普遍的特質の側面 (すなわちサイエン ス)に注目します，更に，そこで本質となる問題を明らかにし，議論を深め問題作りから始めていくことを目的とします，コミュ 二ケーションサイエンスというキーワードは, このように現状の現実の通信システムのみならず, 生体, 更に社会における情報伝 達とインタラクションにおいて多くのサイエンスの芽が潜んでいるという科学的直観を反映するものです.

具体的には下記の分野に垣間見える新領域への取組みが進んでいます.

\author{
通信システムの理論 \\ 分散ネットワークと分散アルゴリズムの理論 \\ 通信システムの基盤としてのパワー, エネルギ一的側面に関する基礎研究 \\ 電力工学と通信システムの界面 \\ 上記4領域と関連する実証的アプローチ, 実システム上の諸問題 \\ 通信システムの技術, 知見から神経系, 生体システムを捉え直す研究 \\ 電磁波伝搬 (フェージングの問題等含む) の理論・モデリングの研究 \\ レーダ, トモグラフィーの計測分野で見られる非線形性, 更に信号レベルで現れる非線形ひずみ等の非線形性が本質と \\ なる諸問題 \\ レーザ等の非線形デバイスと通信システムの界面
}

\section{2. 本CSS研究会のユニークな特徎，参加者へのメリット}

近年の非線形科学の展開の経緯を見ると,「ソリトン」,「カオス・フラクタル」,「複雑系」,「シンクロ (集団同期)」, 更に「複雑ネッ トワーク」というそれぞれ 10年程度のムーブメントが連続してきています. 最近の複雑ネットワークの研究の流行は, インター ネットのリンク構造の全貌を把握しようとする研究が一つの原動力となっていました。つまり，これは通信システムのリアリティ が一つの新しいサイエンスを産み出した例といえるでしょう. そしてインターネットはいうまでもなく, 最近10年のレンジでは, 情報通信とその周辺環境の激変から, 非線形科学の視点からもいまだ問題として定式化すらできていない重要な現実問題が山積し ています.

一方では情報通信の現場に近づくにつれ，「標準化」,「イノベーション」からの拘束条件が研究の方向性を強く支配し，立ち止まっ てゆっくり考える・振り返る余裕はなくなっているのも現実です，そこにはある種の閉塞感も感じられると危惧する声も聞かれま す.

本研究会では，以上のリアリティを直視し，そのギャップを越えて真にフロンティア精神のある研究を焦らず育てていきます ソリトン理論が, 光ソリトン, 全光長距離ファイバ通信システムへと化けていったように, 根気良く現場 (現実) とサイエンス (理想) の橋渡しの場を提供していくべく,一同研さん ·努力をいっております，皆様の御理解, 御支援, 御参加を切にお願し申し上げます 


\section{3. 活動日程}

·第 1 回複雑コミュニケーションサイエンス研究会 (CCS) キックオフ会議

日 時 : 2011 年9月4日(日) 13:00〜 17:00

会＼cjkstart場：神戸市産業振興センター902-903会議室 (http://www.kobe-ipc.or.jp/)

特別招待講演 (50音順)

引原隆士 先生 (京都大学)「物理層の技術開発と非線形科学に基づく通信・電力ネットワークの統合アプローチ」

村田正幸 先生 (大阪大学)「大規模複雑系としての情報ネットワーク」

国際会議 NOLTA 2011 スペシャルセッション企画

日 時：2011年9月5日(月)から3日間

前代未聞 (!?)の計5セッション, 21 件の研究発表が予定されています.

·第2回複雑コミュニケーションサイエンス研究会 (CCS) @ 宮古島

日 時：2011年11月10日(木), 11 月11日(金)の2日間 (予定)

会 場：宮古島マリンターミナル 2F研修室

発表締切：10月11日(火)（まだ間に合います!)

予稿原稿提出締切：10月25日(火)

参加費 : 発表者5,000円 (当日),

聴講者 一般 3,500円(10/31 までに振込の場合 3,000円)，学生無料

以上の詳細は, 下記の研究会サイトにて御覧になれます.

http://synchro4.ee.uec.ac.jp/CCS/

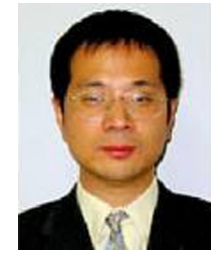

梅野 健 (正員)

1990 早大·理工・電子通信卒.1995東大大学 院理学系研究科院博士課程了. 博士 (理学). 同年理 化学研究所基礎科学特別研究員を経て, 1998郵政 省通信総合研究所 (現NICT) 研究官, 2000 主任研 究官を経て現在, NICT電磁波計測研究所主任研究 員. 2005 2010独立行政法人理化学研究所次世 代移動体通信研究チームリーダー兼務。1998電気学 会優秀論文発表賞, 2000 応用物理学会講演奨励賞, 2003LSIIPアワードIP賞, 2003, 2007テレコム システム技術賞(電気通信普及財団) 各受賞. 日本応 用数理学会, レーザー学会各会員.

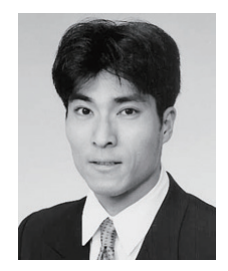

田中久陽 (正員)

1995 早大大学院博士課程了. 工博. 同年から日 本学術振興会特別研究員 (PD). 1996カリフォル二 ア大バークレー校客員研究員.1997からソニーコ ンピューターサイエンス研究所研究員. 2001 電通 大・電気通信 電子. 助教授 (現在，情報·通信·准 教授)。情報通信システム, 非線形物理等の分野横断 的領域の研究に従事. 本会基礎・境界ソサイエティ では2008，2009年度庶務幹事を務める。2006, 2007, 2009第22回電気通信普及財団賞 (テレコ ムシステム技術賞)、第23回，第25回電気通信普及 財団賞 (テレコムシステム奨励賞) 各受賞. 本研究会 代表発起人。

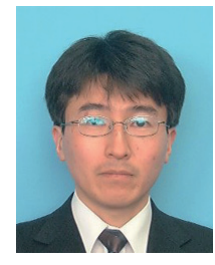

岡本英二 (正員)

1995 京大大学院修士課程了.1995 2002郵 政省通信総合研究所 (現独立行政法人情報通信研究機 構) 郵政技官, 研究員. 2003 から名工大助手 (現在, 大学院工学研究科准教授). 衛星通信, 三リ波無線ア クセスシステム、移動通信に関する研究・教育に従 事. 博士 (情報学)。1999本会学術奨励賞, 2005, 2007,2010本会通ソ活動功労賞，2008 総務省 東海総合通信局長表彰, 2009 船井情報科学奨励賞 各受賞. 